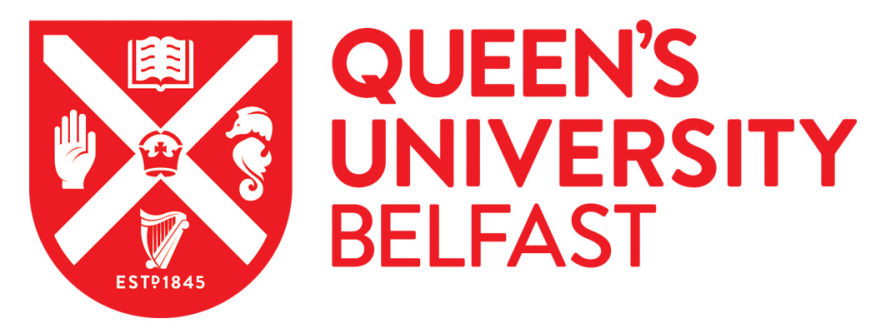

\title{
Physical and mechanical performance of magnesium-based construction boards: A comparative study
}

Aiken, T., McPolin, D., Russell, M., Madden, M., \& Bagnall, L. (2021). Physical and mechanical performance of magnesium-based construction boards: A comparative study. Construction and Building Materials, 270 , [121397]. https://doi.org/10.1016/j.conbuildmat.2020.121397

\section{Published in:}

Construction and Building Materials

\section{Document Version:}

Peer reviewed version

\section{Queen's University Belfast - Research Portal:}

Link to publication record in Queen's University Belfast Research Portal

\section{Publisher rights}

Copyright 2020 Elsevier Ltd.

This manuscript is distributed under a Creative Commons Attribution-NonCommercial-NoDerivs License

(https://creativecommons.org/licenses/by-nc-nd/4.0/), which permits distribution and reproduction for non-commercial purposes, provided the author and source are cited.

\section{General rights}

Copyright for the publications made accessible via the Queen's University Belfast Research Portal is retained by the author(s) and / or other copyright owners and it is a condition of accessing these publications that users recognise and abide by the legal requirements associated with these rights.

Take down policy

The Research Portal is Queen's institutional repository that provides access to Queen's research output. Every effort has been made to ensure that content in the Research Portal does not infringe any person's rights, or applicable UK laws. If you discover content in the Research Portal that you believe breaches copyright or violates any law, please contact openaccess@qub.ac.uk. 


\title{
Physical and mechanical performance of magnesium-based construction boards: A comparative study
}

\author{
Authors: Timothy A Aiken ${ }^{1 *}$, Daniel McPolin ${ }^{1}$, Mark Russell ${ }^{1}$, Molai Madden ${ }^{1}$, Leo Bagnall ${ }^{2}$ \\ ${ }^{1}$ School of Natural and Built Environment, Queen's University Belfast, Stranmillis Road, Belfast, \\ Northern Ireland, BT9 5AG \\ ${ }^{2}$ Resistant Building Products, 7 Duncrue Place, Belfast, Northern Ireland, BT3 9BU \\ * corresponding author email address - taiken02@qub.ac.uk
}

\begin{abstract}
The use of sheeting materials within the construction industry is becoming increasingly common as building materials and the way they are used evolves. Recently, magnesium-based construction boards have received more attention as alternatives for traditional sheeting materials. This is due to some of their enhanced properties, particularly fire resistance and lower embodied carbon. However, the lack of standardised documentation has caused concern regarding their composition, performance and longterm behaviour. This paper evaluates some of the test methods commonly used when assessing the performance of construction boards. A comparison between relatively novel magnesium-based boards and traditional boards is also conducted. Physical, mechanical and durability properties are investigated. Magnesium-based boards can provide relatively good bending strength values and water absorption behaviour which is comparable with other board types. Findings also demonstrate good performance for magnesium-based boards when exposed to soak-dry and freeze-thaw cycles. They suffered relatively small changes in bending strength, similar to that of fibre cement boards and superior to that of gypsum plasterboard and wood-based boards.
\end{abstract}

Keywords: $\mathrm{MgO}$ boards; magnesium oxychloride cement; water absorption; gypsum plasterboard; durability

\section{Introduction}

The demand within the construction industry for sheeting materials or construction boards is huge and continues to grow. This is due to several factors including the wide range of applications for which boards can be used. They can serve a variety of internal and external functions including sheathing, wall/ceiling linings, render carrier systems and prefabricated wall systems [1-3]. Construction boards are also well suited to off-site construction methods, which are becoming increasingly more common. This allows for faster, less expensive and more environmentally friendly construction compared to traditional on-site methods [4-6]. 
In recent years magnesium cement based boards have become more widely used replacing traditional board types such as fibre or calcium silicate cement, gypsum plasterboards and wood-based boards. They are produced from a combination of magnesium cement binder, lightweight fillers (such as wood fibre and perlite) and reinforcing glass fibre mesh on their outer surface. One of their main advantages is that they possess excellent fire resistance [7-9]. This is because the binder transforms into magnesium oxide $(\mathrm{MgO})$ with a very high melting point (approximately $2800{ }^{\circ} \mathrm{C}$ ) during fire exposure [10]. In addition they contain a significant amount of bound water which is released at increased temperatures and acts as a fire retardant and smoke suppressant [10]. There are two main types of magnesium cement binder commonly used, namely magnesium oxychloride and magnesium oxysulphate.

Reports [11-13] from Denmark have highlighted durability problems associated with the use of magnesium oxychloride boards. Specifically, the formation of moisture containing chloride ions on the surface of the boards causing mould growth on timber elements and the corrosion of steel fixtures and fittings. However, recent studies [2,14] have compared the performance of different magnesium oxychloride boards and found that there is a significant difference in performance from one board to another. Specifically, when exposed to moisture some boards displayed behaviour similar to that observed in Denmark whilst others did not. The better performing boards did not result in any moisture formation on their surface after accelerated exposure conditions. The reports from Denmark have driven some sectors of the construction industry towards the use of magnesium oxysulphate boards instead, mainly because they do not contain significant quantities of chloride ions. However, there is limited information in literature on the durability of magnesium oxysulphate boards. Previous studies suggest that magnesium oxysulphate cements have lower mechanical properties than that of magnesium oxychloride cements and suffer from the same loss of strength upon exposure to water [15-17]. Poor resistance to water has therefore hindered the use of magnesium oxychloride and oxysulphate cements for mainstream cement and concrete applications [18]. Instead they are more suited to board applications as they do not often encounter direct exposure to moisture in-service. In addition many other board types such as fibre cement, gypsum plasterboard, plywood and oriented strand board (OSB) also have a degree of susceptibility to moisture but are still suitable for board applications [19-26].

At present, no specific standard documentation exists for magnesium oxychloride or magnesium oxysulphate boards. A specific standard does exist for fibre cement type boards [27] which allows assessment of fibre cement boards to a specific set of tests. This allows consumers to select fibre cement boards with superior performance and reduces the use of poor quality products which in turn diminishes the amount of problems in-service. A similar dedicated standard is needed for magnesium type boards. This paper assesses the performance of magnesium-based boards and compares their performance with traditional board types including fibre cement, gypsum plasterboard and wood-based boards. The most appropriate standards were selected for assessment of physical characteristics and durability using 
guidance from BS EN 12467 [27] and BS EN 323:1992 [28] and BS EN ISO 15148:2002+A1:2016 [29]. These tests and standard documents were chosen as they are the most relevant existing standard test procedures for sheeting materials used in the construction industry. Warm water testing was not conducted as it is relevant only to high $\mathrm{pH}$ cements with soluble reinforcement [30-32]. The relevant tests and standards that were used are summarized in Table 1 below.

Table 1 Test and relevant standards used for assessment of magnesium-based boards

\begin{tabular}{cll}
\hline Category & \multicolumn{1}{c}{ Test } & \multicolumn{1}{c}{ Test standard } \\
\hline \multirow{2}{*}{$\begin{array}{c}\text { Physical and } \\
\text { mechanical } \\
\text { properties }\end{array}$} & Apparent density & Conducted using guidance from BS EN 323:1992 \\
& Water absorption & $\begin{array}{l}\text { Conducted using guidance from BS EN 12467 } \\
\text { Conducted using guidance from BS EN ISO } \\
15148: 2002+A 1: 2016\end{array}$ \\
\hline \multirow{2}{*}{ Durability } & Soak-dry & $\begin{array}{l}\text { Conducted using guidance from BS EN 12467 } \\
\end{array}$ \\
& Freeze-thaw & Conducted using guidance from BS EN 12467 \\
& Moisture movement & Conducted using guidance from BS EN 12467 \\
\hline
\end{tabular}

The development of a Publicly Available Specification (PAS) standard document (PAS 670:2021) for magnesium-based construction boards under The British Standards Institution (BSI) was initiated in May 2020 in conjunction with the magnesium oxide building board trade association (MOBBTA).

\section{Experimental methods}

\subsection{Board samples}

Five board types were obtained for analysis and comparison: magnesium oxychloride (MC), magnesium oxysulphate (MS), fibre cement (FC), gypsum plasterboard (GP) and wood-based (WB). Furthermore, two samples of each board type, obtained from different manufacturers, were selected for investigation. The fibre cement boards used may also be described as calcium silicate cement boards. As this is an investigative study exploring the properties of industrial products, the exact proportions of raw materials used in each board is not known. Each of the boards are available in the UK market and are identified in Table 2 by code and type. Their nominal thickness and density, which was obtained according to BS EN 323:1992 [28], is also provided. The two MC boards were selected from a previous study [14] that assessed the variability of magnesium oxychloride boards within the market. Within the previous study these boards, MC1 and MC2, were referred to as boards A and D, respectively. 
Table 2 Thickness and density of ten construction board samples

\begin{tabular}{cccc}
\hline Board code & Type & Nominal thickness $(\mathrm{mm})$ & Density $\left(\mathrm{kg} / \mathrm{m}^{3}\right)$ \\
\hline MC1 & \multirow{2}{*}{ Magnesium oxychloride } & 9.0 & 1092 \\
MC2 & & 9.0 & 993 \\
MS1 & Magnesium oxysulphate & 12.0 & 1077 \\
MS2 & & 9.0 & 1063 \\
FC1 & Fibre cement & 12.0 & 1295 \\
FC2 & & 9.0 & 1453 \\
GP1 & \multirow{2}{*}{ Gypsum plasterboard } & 12.0 & 814 \\
GP2 & & 12.0 & 700 \\
WB1 & \multirow{2}{*}{ Wood-based OSB } & 12.0 & 634 \\
WB2 & & 11.0 & 556 \\
\hline
\end{tabular}

Fig. 1 shows photographs of the top surface and cross-section of each board. The MC and MS boards are white in colour due to the white colour of magnesium oxychloride and magnesium oxysulphate cement. They also contain perlite which is white in colour. Brown wood fibres are also visible in the cross-section of each magnesium-based board, particularly MC2 an MS2. The MC and MS boards also have layers of fibre glass mesh just below the top and bottom surface of each board. The FC boards appear yellowish/light brown and are more homogenous when comparing the appearance of their crosssection. They typically contain cement, limestone, cellulose fibres and fillers including mica and kaolin [33]. Original fibre cement technology involved the use of asbestos but has since been replaced with cellulose due to health and safety concerns with asbestos [34]. The ingredients in current fibre cement boards is similar to the ingredients found in boards often described as calcium silicate cement boards [35-37]. The gypsum plaster boards have layers of paper on either side of gypsum cement. The back layer is brown in colour while the front layer of paper is coloured to signify the type and specific use. GP1 is pink and designed for fire protection, GP2 is green and designed for use in humid environments. WB1 is a type of orientated strand board (OSB) which is designed for use in humid environments. It is produced from softwood flakes and strips which are coated with adhesive and pressed together in specific orientations. WB2 is a softwood plywood which is composed of seven thin layers of wood which are glued together. 


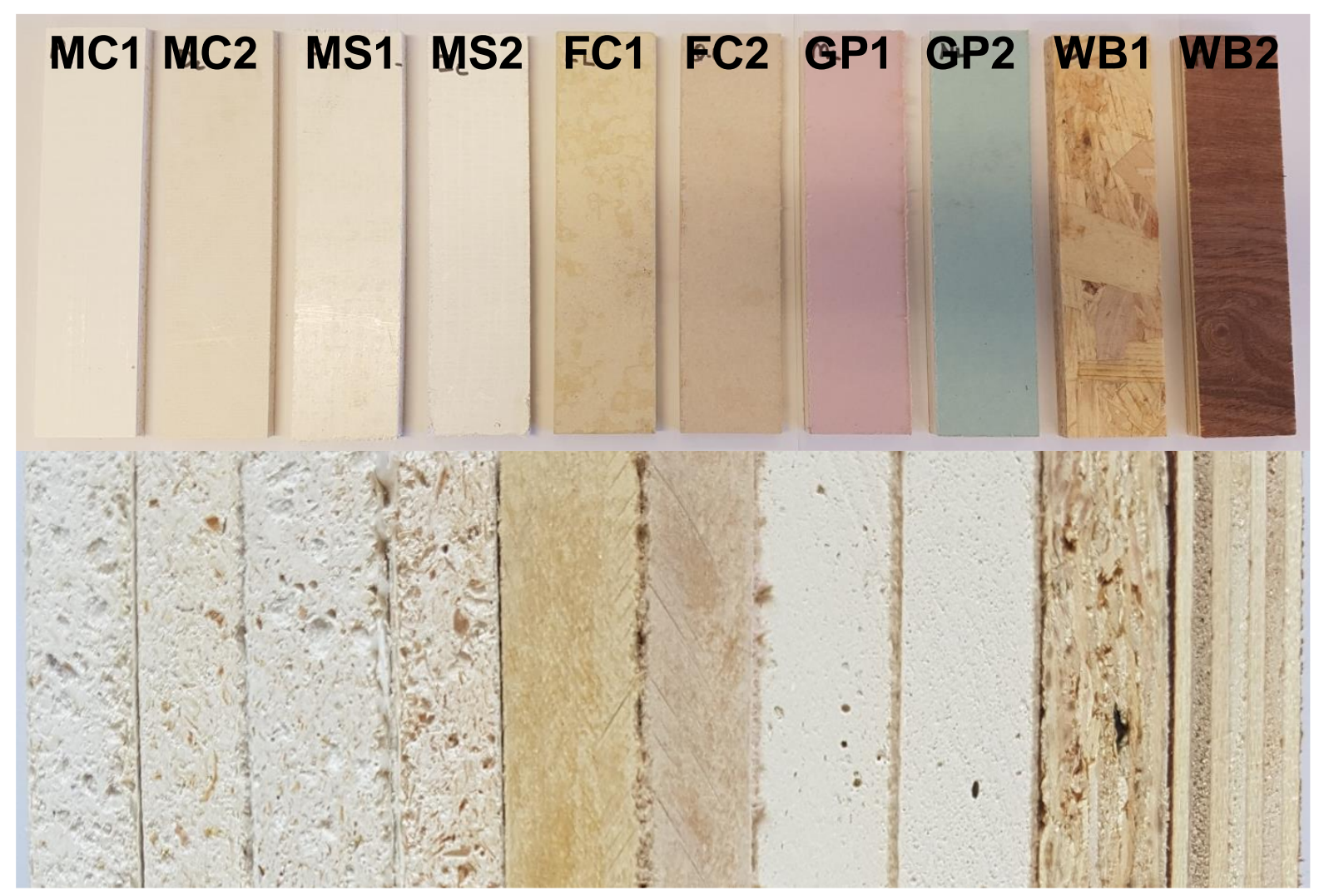

Fig. 1. Photos of the top surface and cross-section of each board.

\subsection{Testing procedures}

\subsubsection{Mineralogical composition}

The composition of each board was examined by X-ray diffraction (XRD). XRD was carried out with a PANalytical X'Pert PRO MPD diffractometer, using $\mathrm{CuK} \alpha$ radiation of wavelength $1.54 \AA$. The mineralogy of the various samples was ascertained by using X'Pert Highscore Plus software in conjunction with the Powder Diffraction File database. Diffraction patterns were obtained between 5 and $65^{\circ} 2 \theta$ with a step size of $0.02^{\circ} 2 \theta$. XRD was carried out on powdered samples of each board with a particle size $\leq 63 \mu \mathrm{m}$.

\subsubsection{Physical and mechanical properties}

The modulus of rupture, or bending strength, of each board was obtained using guidance from the method described in BS EN 12467:2012+A2:2018 [27]. Three rectangular specimens measuring $200 \mathrm{x}$ $50 \mathrm{~mm}$ were cut from both the longitudinal and transverse directions and stored in ambient laboratory conditions for more than 7 days prior to testing. A three-point bending test was conducted with a span of $150 \mathrm{~mm}$ and a loading rate of $10 \mathrm{~mm} / \mathrm{min}$. The average of all 6 samples was then calculated to obtain the bending strength for each board. 
The water absorption coefficient was obtained according to the partial immersion procedure given in BS EN ISO 15148:2002+A1:2016 [29]. Three samples measuring 100 x $100 \mathrm{~mm}$ were tested for each board. The outside edge of each sample was coated was epoxy paint to prevent any water ingression from the sides of the sample. The samples were then conditioned under test conditions $\left(23 \pm 2{ }^{\circ} \mathrm{C}\right.$ and $50 \pm 5 \%$ relative humidity $(\mathrm{RH})$ until two consecutive mass readings $24 \mathrm{~h}$ apart were stabilised to within $1 \%$ of the samples mass. The initial mass was then recorded and the samples placed with their top face down in contact with water as shown in Fig. 2. After intervals of 5 min, 20 min, 1 h, 2 h, 4 h, 8 h, 24 h and $48 \mathrm{~h}$, the samples were removed from the water, the surfaces gently dried and the mass recorded. The samples were then returned to the water until the subsequent measurement. The water level in the container was also maintained. A graph of the change in mass over surface area is plotted against the square root of time and the water absorption coefficient calculated according to the guidance in BS EN ISO 15148:2002+A1:2016 [29].

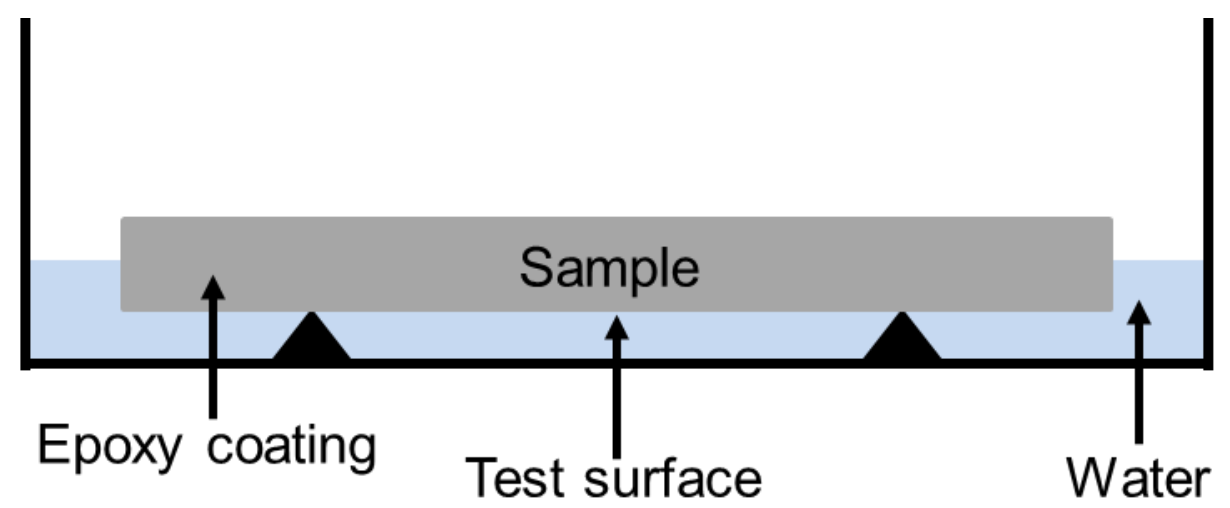

Fig. 2. Schematic diagram of setup for water absorption test.

\subsubsection{Durability performance}

The durability performance of each board was assessed in general accordance with three procedures described in BS EN12467 [27] as soak-dry, freeze-thaw and moisture movement.

For the soak-dry and freeze-thaw tests, samples measuring 200 x $50 \mathrm{~mm}$ were used. Three samples were tested from both the longitudinal and transverse direction of each board. A three-point bending test was conducted with a span of $150 \mathrm{~mm}$ and a loading rate of $10 \mathrm{~mm} / \mathrm{min}$. The average of all six samples was then calculated to obtain the bending strength. Control or reference bending strengths for each board were obtained by immersing samples in water for $24 \mathrm{~h}$. Then following exposure to soak-dry and freezethaw cycles the bending strength was measured for comparison with the control samples. The soak-dry test involved immersion of samples in water $\left(20 \pm 4{ }^{\circ} \mathrm{C}\right)$ for $18 \mathrm{~h}$ followed by drying in a ventilated oven at $60{ }^{\circ} \mathrm{C}$ for $6 \mathrm{~h}$. This was repeated for 25 cycles. When breaks between cycles were necessary, the samples were kept in immersed conditions for up to $72 \mathrm{~h}$. Samples were immersed in separate containers according to their type (MC, MS, FC, GP and WB). During the freeze-thaw test the samples 
were subjected to cycles of cooling and heating. They were cooled in a climate chamber at a temperature of $-20{ }^{\circ} \mathrm{C}$ for $2 \mathrm{~h}$ followed by heating in a water bath at a temperature of $20 \pm 4{ }^{\circ} \mathrm{C}$ for at least $3 \mathrm{~h}$. A total of 25 cycles were carried out. When breaks between cycles were necessary, the samples were kept in immersed conditions for up to $72 \mathrm{~h}$. Samples were immersed in separate containers according to their type (MC, MS, FC, GP and WB). The mass and thickness of each board was also recorded before and after exposure.

The linear moisture movement of each board was obtained in general accordance with BS EN 12467:2012+A2:2018 [27]. One sample from each direction of each board was tested and the average calculated. The size of samples used was $250 \times 75 \mathrm{~mm}$. Each sample had two demec datum discs fixed to its surface $200 \mathrm{~mm}$ apart. The samples were conditioned at $23{ }^{\circ} \mathrm{C}$ and $30 \% \mathrm{RH}$ until they reached constant mass. At this point the distance between the two discs was measured using a demountable mechanical strain gauge. The RH was then increased to $90 \%$ for 22 weeks and the distance between the two discs measured again. The linear moisture movement was then calculated as a percentage change between the two readings.

\section{Results and discussion}

\subsection{Mineralogical composition}

Fig. 3 shows the XRD patterns of each board. Each pair of boards within each board type display very similar patterns. The main product found in the magnesium oxychloride boards ( $\mathrm{MC} 1$ and $\mathrm{MC} 2$ ) is fivephase magnesium chloride hydroxide hydrate $\left(5 \mathrm{Mg}(\mathrm{OH})_{2} \cdot \mathrm{MgCl}_{2} \cdot 8 \mathrm{H}_{2} \mathrm{O}\right)$. Other phases of this type may also be formed in magnesium oxychloride cements depending on the curing temperature and molar ratios employed [38-41]. However, the five-phase identified in these two boards has been reported as the preferable phase for structural applications due its mechanical properties [42]. Other products identified in the two magnesium oxychloride boards are brucite $\left(\mathrm{Mg}(\mathrm{OH})_{2}\right)$, magnesite $\left(\mathrm{MgCO}_{3}\right)$, and quartz $\left(\mathrm{SiO}_{2}\right)$. Brucite is likely formed due to hydration of unreacted $\mathrm{MgO}$. Magnesite could be present due to incomplete calcination of raw magnesite or carbonation of unreacted $\mathrm{MgO}$. There are also likely small quantities of periclase $(\mathrm{MgO})$, dolomite $\left(\mathrm{CaMg}\left(\mathrm{CO}_{3}\right)_{2}\right)$, calcite $\left(\mathrm{CaCO}_{3}\right)$ and talc $\left(\mathrm{Mg}_{3} \mathrm{Si}_{4} \mathrm{O}_{10}(\mathrm{OH})_{2}\right)$ present as identified in a previous publication [14]. The main component of the magnesium oxysulphate boards is magnesium oxysulphate hydrate $\left(5 \mathrm{Mg}(\mathrm{OH})_{2} \cdot \mathrm{MgSO}_{4} \cdot 7 \mathrm{H}_{2} \mathrm{O}\right)$, termed 5-1-7 [10]. These boards also contain, brucite, magnesite, calcite and quartz. The fibre cement boards (FC1 and FC2) are dominated by the presence of quartz. They also contain calcite and tobermorite $\left(\mathrm{Ca}_{5} \mathrm{Si}_{16}(\mathrm{OH})_{2} \cdot 4 \mathrm{H}_{2} \mathrm{O}\right)$. $\mathrm{FC} 2$ appears to have less tobermorite and more calcite than FC1. Tobermorite is desirable as it provides low density and good thermal insulation properties. Its formation is dependent on the autoclave curing temperature and duration [37,43]. The gypsum plasterboards (GP1 and GP2) as expected contain an abundance of gypsum $\left(\mathrm{CaSO}_{4} \cdot 2 \mathrm{H}_{2} \mathrm{O}\right)$. The wood-based boards (WB1 and WB2), 
due to their high organic content, are X-ray amorphous as exhibited by the broad humps located between 10 and $30^{\circ} 2 \theta[44]$.

5-5-phase B-brucite M-magnesite Q-quartz C-calcite 5-1-7-magnesium oxysulfate hydrate G-gypsum T-tobermorite

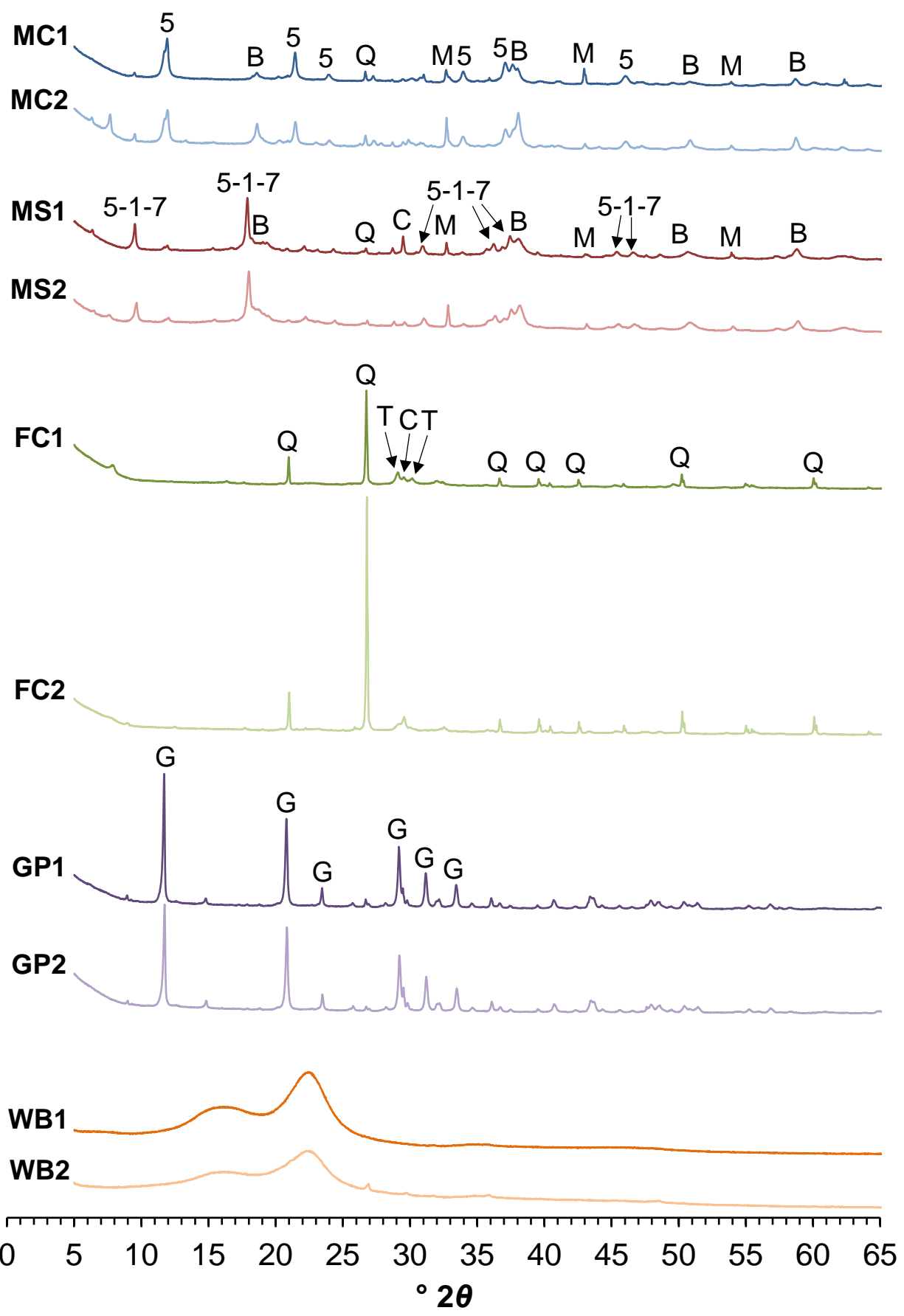

Fig. 3. XRD pattern of each board. 


\subsection{Physical and mechanical properties}

Fig. 4 shows the modulus of rupture or bending strength for each board. These samples were tested in a dry condition following storage in ambient laboratory conditions. The dashed lines represent the five strength classes given in BS EN 12467 [27]. The average deflection for each board at rupture is provided in Table 3. The wood-based boards displayed the largest bending strength values: 37.8 and $24.0 \mathrm{MPa}$ for the plywood and OSB respectively. These boards also had the largest variability as shown by the error bars. They also had an increased deflection at rupture compared with most of the other boards. MC1 had a modulus of rupture of 23.0 MPa. The fibre cement boards had almost identical values of 17.7 and 17.6 MPa for FC1 and FC2, respectively. The other three magnesium-based boards had similar modulus of rupture values of 11.7, 10.7 and 9.2 MPa for MS2, MS1 and MC2, respectively. The increased strength observed for MC1 compared with MC2 could be due to the apparent increase in 5phase content according to XRD (Fig. 3). The smallest values were obtained for the gypsum plasterboards; 5.0 and 4.5 for GP1 and GP2, respectively. The MC and MS boards have layers of glass fibre mesh just below their top and bottom surface which likely contribute to their strength achieved. Whereas FC boards typically have embedded cellulose fibres which contribute to their strength. These findings demonstrate that magnesium-based construction boards can provide strength values better or equal to fibre cement and gypsum plasterboards.

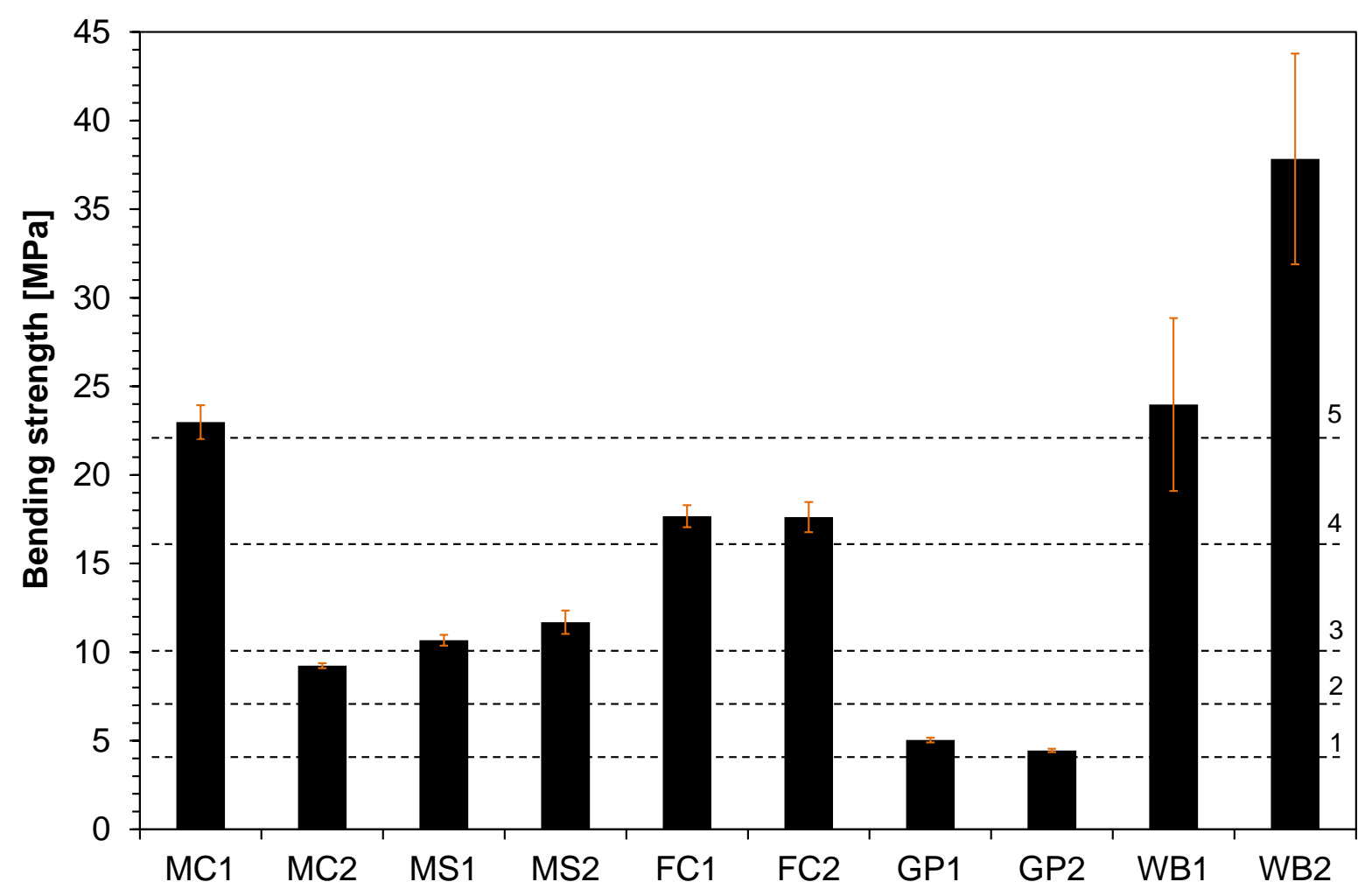

Fig. 4. Bending strength for each board. 
Fig. 5 shows the extent of water absorption by partial immersion, plotted as the change of mass against the square root of time as recommended in BS EN ISO 15148 [29]. The fibre cement boards had the largest change in mass, followed by the magnesium-based boards which were quite variable from one to another. $\mathrm{MC1}$, the gypsum plasterboards and wood-based boards appeared to absorb the least moisture. The uptake of moisture was slow and steady for the gypsum plasterboards and WB1 (OSB).

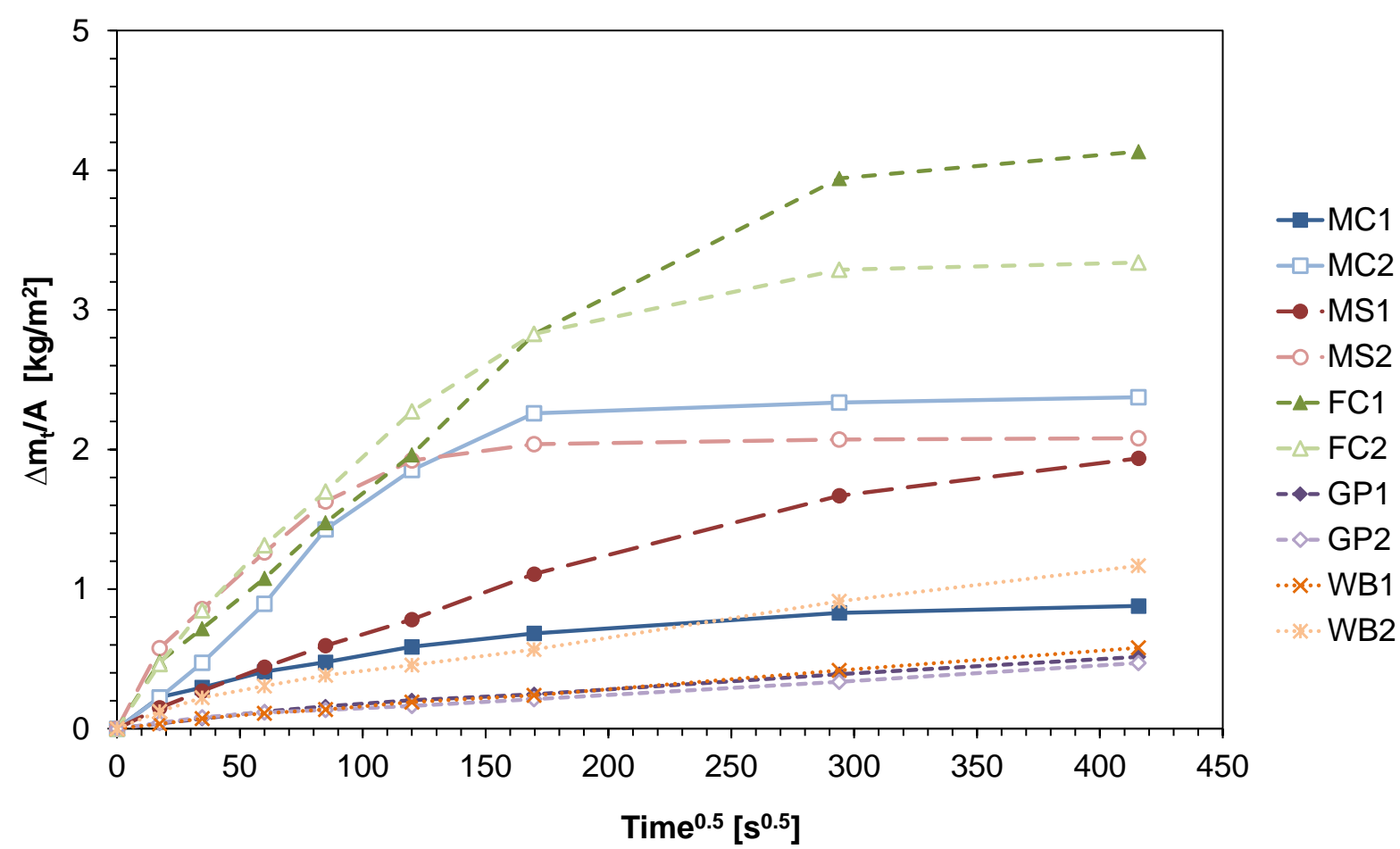

Fig. 5. Water absorption by partial immersion - change in mass over surface area against square root of time.

According to the classification in BS EN ISO 15148 [29], the graph for each sample will be type A or $B$ and the water absorption coefficient $\left(\mathrm{A}_{\mathrm{w}}\right)$ is calculated accordingly. The classification and water absorption coefficient values for each board are shown in Table 3. The smallest water absorption coefficient values were obtained by GP1, GP2 and WB1 $\left(0.0011-0.0014 \mathrm{~kg} / \mathrm{m}^{2} \cdot \mathrm{s}^{0.5}\right)$ followed by WB2, MC1 and MS1 $\left(0.0025-0.0052 \mathrm{~kg} / \mathrm{m}^{2} \cdot \mathrm{s}^{0.5}\right)$. MC2 and MS2 had significantly larger water absorption coefficient values of 0.0132 and $0.0136 \mathrm{~kg} / \mathrm{m}^{2} \cdot \mathrm{s}^{0.5}$, respectively. Finally, the largest water absorption was obtained by the fibre cement boards $\left(0.0156\right.$ and $\left.0.0154 \mathrm{~kg} / \mathrm{m}^{2} \cdot \mathrm{s}^{0.5}\right)$. This could be related to the high water absorption of cellulose fibres used in this board type [23]. The paper surface on the gypsum plasterboards appears effective at limiting water absorption. Likewise, the glue bonding the wood pieces appears to help slow the rate of water uptake in WB1. However, it is worth noting that for the gypsum plasterboards and wood-based boards the uptake of moisture was still increasing steadily at the end of the test. Whereas for some of the other boards the change in mass has ceased indicating no further moisture was being absorbed. These findings indicate the magnesium-based boards have performance 
which is somewhere between that of the gypsum plasterboards/wood-based boards and the fibre cement boards.

Table 3 Water absorption by partial immersion and deflection at rupture for each board

\begin{tabular}{ccccccc}
\hline Board & Type & $\Delta \mathrm{m}_{\text {tf }}^{\prime}$ & $\Delta \mathrm{m}_{0}^{\prime}$ & $\mathrm{t}_{\mathrm{f}}$ & $\mathrm{A}_{\mathrm{w}}$ & $\begin{array}{c}\text { Deflection at } \\
\text { rupture }(\mathrm{mm})\end{array}$ \\
\hline MC1 & $\mathrm{A}$ & 0.683 & 0.21 & 28800 & 0.0028 & 4.60 \\
MC2 & $\mathrm{A}$ & 2.259 & 0.02 & 28800 & 0.0132 & 1.26 \\
MS1 & $\mathrm{A}$ & 1.669 & 0.13 & 86400 & 0.0052 & 1.55 \\
MS2 & $\mathrm{A}$ & 1.921 & 0.29 & 14400 & 0.0136 & 2.28 \\
FC1 & $\mathrm{A}$ & 2.825 & 0.18 & 28800 & 0.0156 & 1.52 \\
FC2 & $\mathrm{A}$ & 2.829 & 0.21 & 28800 & 0.0154 & 1.78 \\
GP1 & $\mathrm{A}$ & 0.391 & 0.021 & 86400 & 0.0013 & 2.98 \\
GP2 & $\mathrm{A}$ & 0.336 & 0.018 & 86400 & 0.0011 & 3.00 \\
WB1 & $\mathrm{A}$ & 0.417 & 0.015 & 86400 & 0.0014 & 4.48 \\
WB2 & $\mathrm{A}$ & 0.913 & 0.17 & 86400 & 0.0025 & 7.36 \\
\hline
\end{tabular}

\subsection{Durability performance}

Fig. 6 shows photographs of each board following exposure to soak-dry and freeze-thaw. They can be compared with photographs of the unexposed samples shown in Fig. 1. The samples exposed to soakdry appear relatively unchanged. Some damage can be noted to the paper on the surface of GP1 and GP2. WB1 and WB2 appear black in colour, this is likely due to the leaching of chemicals during immersion in water as the water became very dark in colour. Following exposure to freeze-thaw the paper has been removed from GP1, leaving behind a rough surface. The GP1 samples were too weak to test, as they broke upon handling. The samples of GP2 were broken during the freeze-thaw cycles, mostly between cycles 15 and 20 .

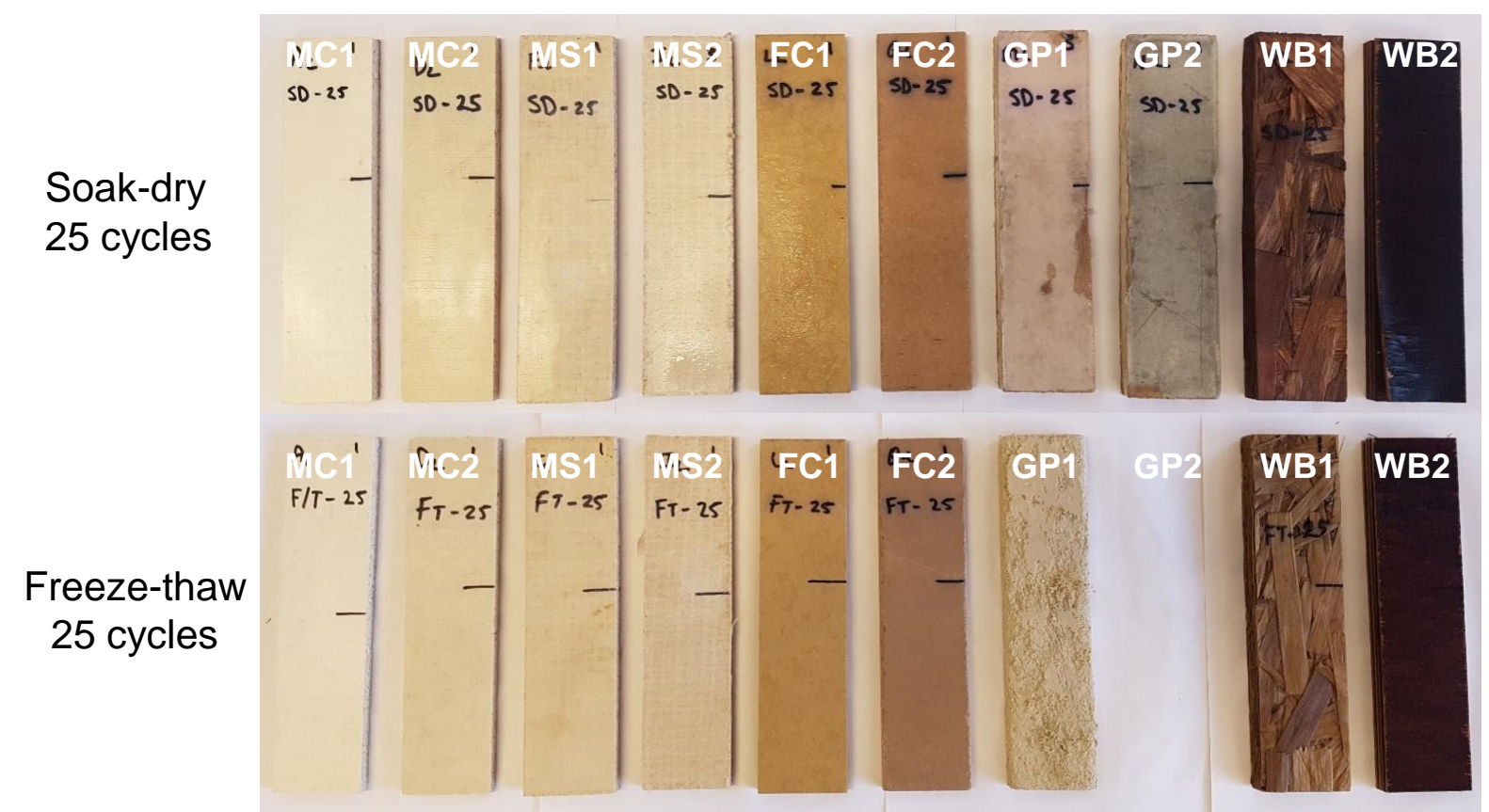

Fig. 6. Photographs of each board after exposure to soak-dry and freeze-thaw. 
Table 4 shows the mass, thickness and bending strength change of each board following exposure to soak-dry and freeze-thaw. The mass of each board increased significantly because they were dry before exposure and subsequently took up moisture during the various exposure conditions. The magnesium oxychloride, magnesium oxysulphate and fibre cement boards all gained between 17 and $37 \%$ mass during exposure to soak-dry and freeze-thaw. The largest increase in mass was observed for the woodbased boards with a gain of more than $100 \%$ observed in some circumstances. This is likely due to the thickness changes and swelling observed for WB1 and WB2 resulting in a larger sample volume to contain moisture. Fig. 7 shows a photograph of a swollen WB1 sample following 25 soak-dry cycles. The thickness change for each of the other boards was relatively small $(\leq 1.3 \%)$.

Table 4 Mass, thickness and bending strength change (\%) of each board following exposure to soakdry and freeze-thaw.

\begin{tabular}{ccccccc}
\hline & \multicolumn{2}{c}{ Mass change (\%) } & \multicolumn{2}{c}{ Thickness change $(\%)$} & \multicolumn{2}{c}{ Bending strength change $(\%)$} \\
Sample & Soak-dry & Freeze-thaw & Soak-dry & Freeze-thaw & Soak-dry & Freeze-thaw \\
\hline MC1 & 22 & 36 & -0.1 & -0.3 & 6 & 6 \\
MC2 & 26 & 37 & -0.2 & -0.3 & -4 & 8 \\
MS1 & 17 & 19 & -0.3 & -0.3 & -7 & 2 \\
MS2 & 23 & 31 & -0.4 & 0.7 & -2 & -13 \\
FC1 & 30 & 34 & -0.1 & 0.2 & 7 & 4 \\
FC2 & 22 & 26 & 0.0 & 1.0 & -2 & -11 \\
GP1 & 44 & - & 1.3 & - & -36 & - \\
GP2 & 53 & - & 0.1 & - & -52 & - \\
WB1 & 114 & 134 & 38.0 & 39.2 & -40 & -21 \\
WB2 & 74 & 102 & 5.1 & 5.6 & -9 & -52 \\
\hline
\end{tabular}

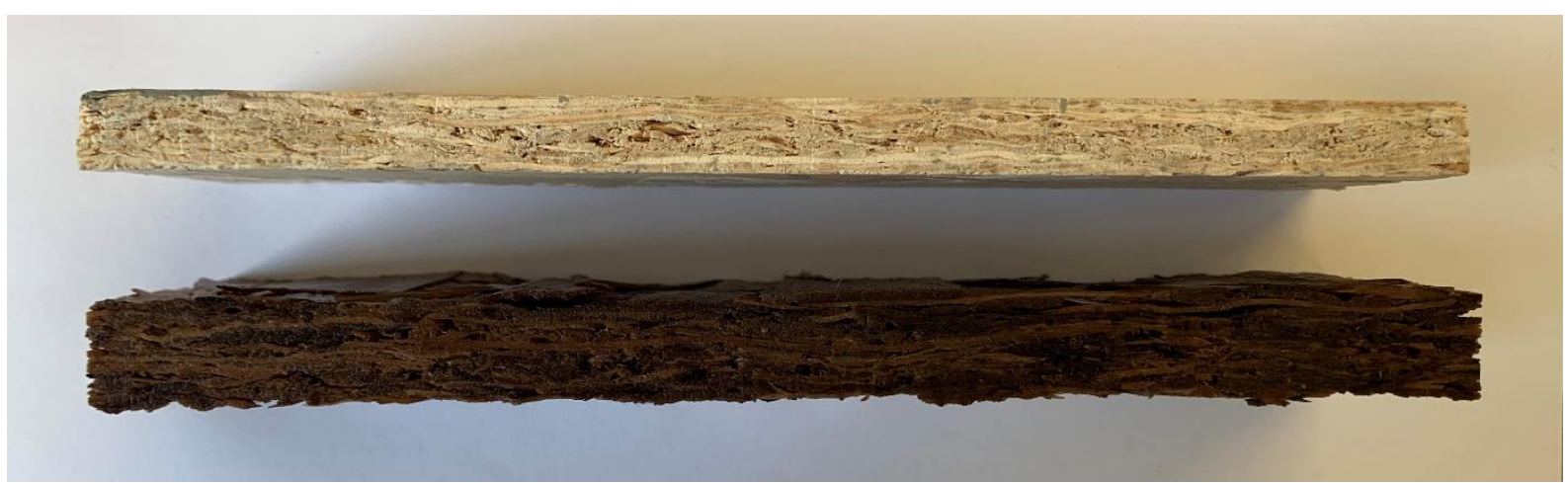

Fig. 7. Photograph of swollen WB1 (OSB) following 25 soak-dry cycles. Unexposed sample also shown for comparison.

Fig. 8 shows the bending strength of each board following exposure to soak-dry and freeze-thaw. The bending strength of control samples stored in water for $24 \mathrm{~h}$ is also shown for comparison. The bending strength change $(\%)$ is shown in Table 4 . After exposure to soak-dry and freeze-thaw no significant change was observed for the magnesium oxychloride (MC1 and MC2), magnesium oxysulphate (MS1 
and MS2) and fibre cement (FC1 and FC2) boards. Each of these boards attained bending strength values similar to that of the control samples with changes $\leq 8 \%$ in most cases which was generally within the range of experimental variation shown by the error bars in Fig. 8. MS2 and FC2 had slightly larger strength losses of 13 and $11 \%$, respectively. It was not possible to obtain the bending strength of the gypsum plasterboard samples after freeze-thaw cycles as they were too badly damaged and weakened. After exposure to soak-dry cycles they had bending strengths of less than $0.5 \mathrm{MPa}$, which equated to bending strength losses of 36 and 52\% for GP1 and GP2, respectively. The wood-based boards suffered considerable bending strength losses in each exposure condition. Most of these were likely due to the expansion caused by uptake of moisture and freezing of water allowing weakening of the bond between wood layers (plywood) and pieces (OSB). Fig. 9 shows a photograph of WB2 (plywood) which had two outside layers partially delaminated after 25 freeze-thaw cycles.

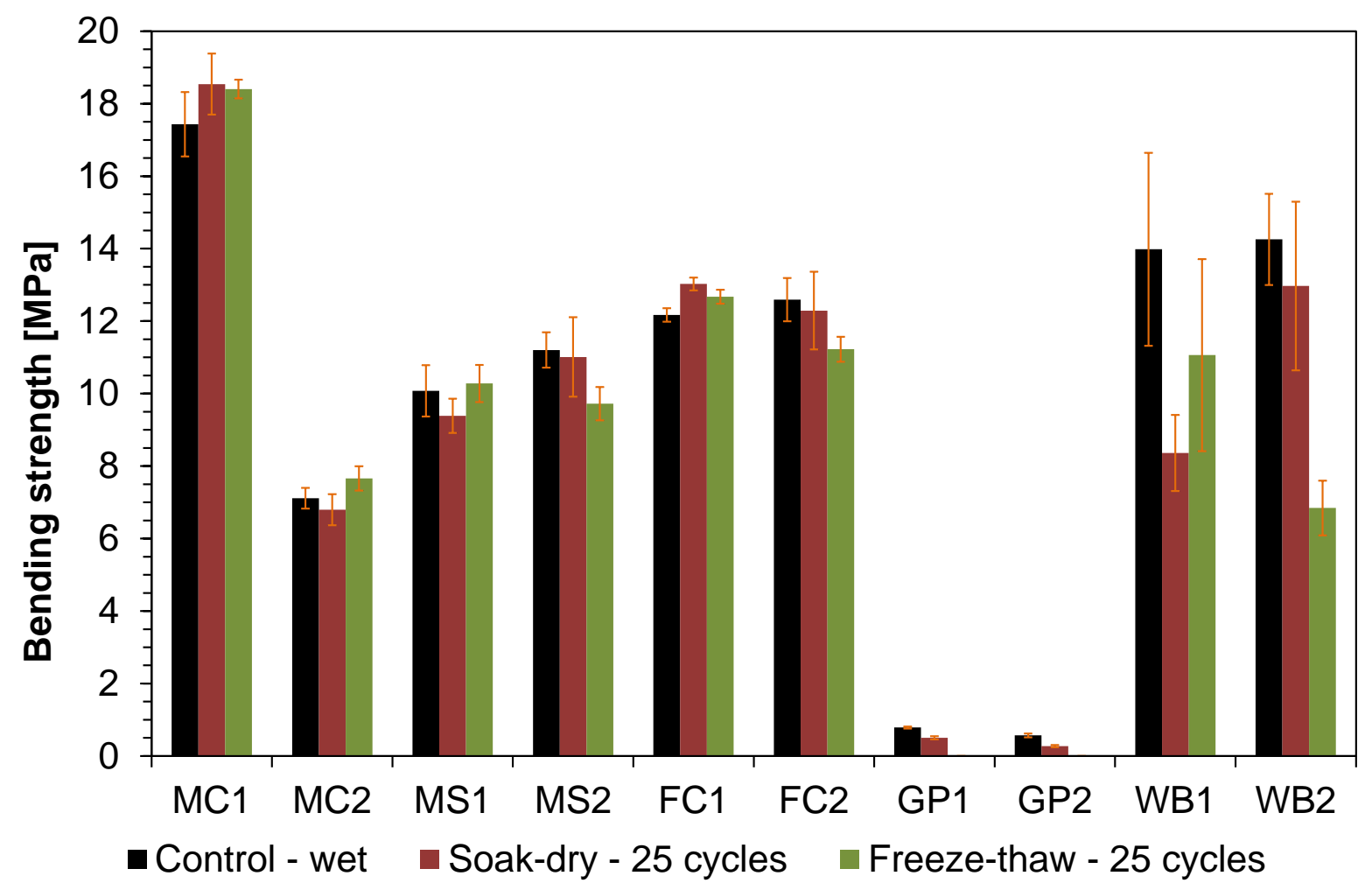

Fig. 8. Bending strength of each board following exposure to soak-dry and freeze-thaw. Bending strength of control samples stored in water for $24 \mathrm{~h}$ are also shown for comparison. 


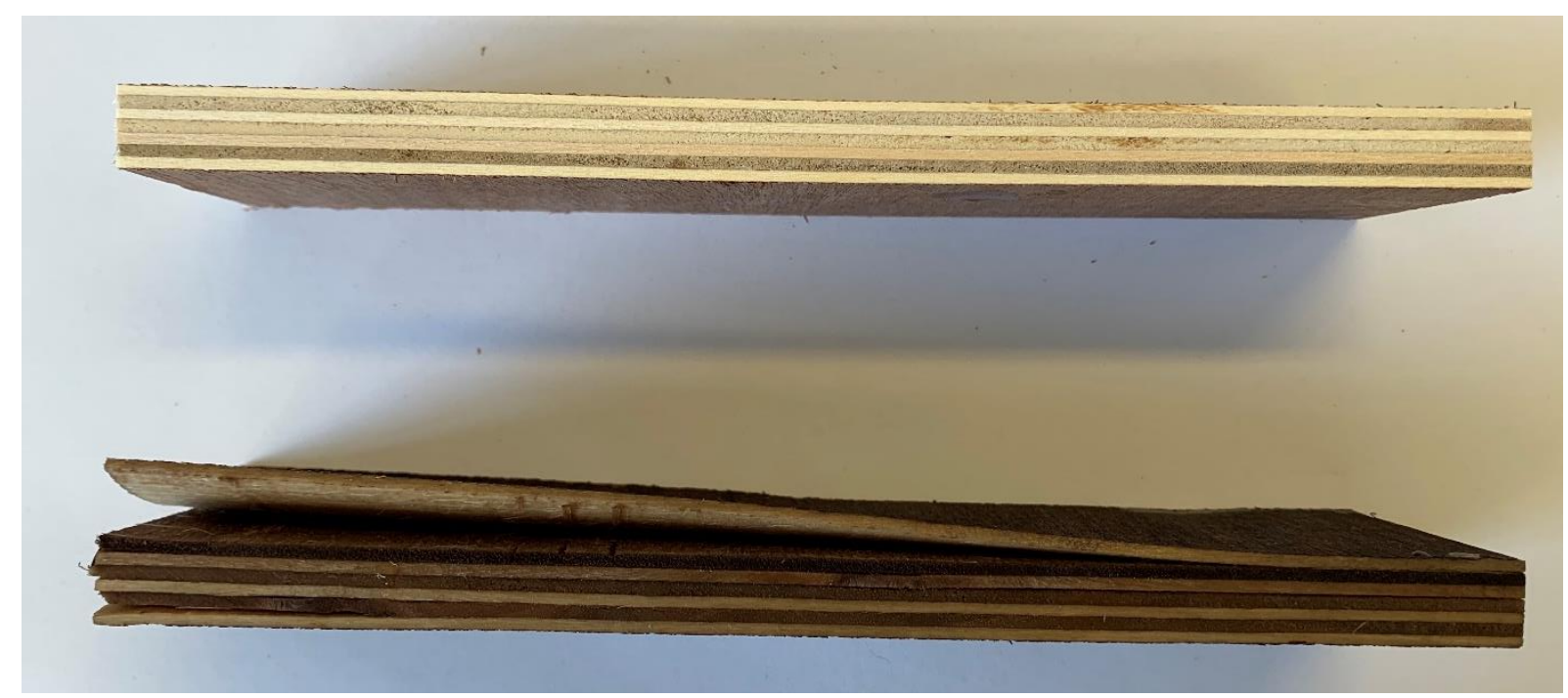

Fig. 9. Photograph of WB2 (plywood) following 25 freeze-thaw cycles. Unexposed sample also shown for comparison.

Fig. 10 displays the linear moisture movement for each board. The smallest moisture movements of $0.04 \%$ was observed for the gypsum plasterboards. The magnesium oxychloride boards also performed well with only 0.07 and $0.05 \%$ moisture movement observed for $\mathrm{MC} 1$ and $\mathrm{MC} 2$, respectively. This good performance is likely related to the ability of these boards to resist transformation of five-phase to other phases during exposure to high RH [14]. The fibre cement boards had moisture movement values of 0.09 and $0.07 \%$ for FC1 and FC2, respectively. This is likely due to the presence of cellulose fibres which make fibre cement boards susceptible to dimensional instability when they become moist $[45,46]$. Significantly larger moisture movement values were observed for the magnesium oxysulphate boards, 0.18 and $0.15 \%$ for MS1 and MS2, respectively. The wood-based boards also endured significant moisture movements of 0.14 and $0.16 \%$ for WB1 and WB2, respectively. Moisture movement is a key parameter for construction boards as it is indicative of length change or expansion following changes in RH. Significant expansion of construction boards can cause significant damage including the failure of fixtures/fittings and the delamination of render. 


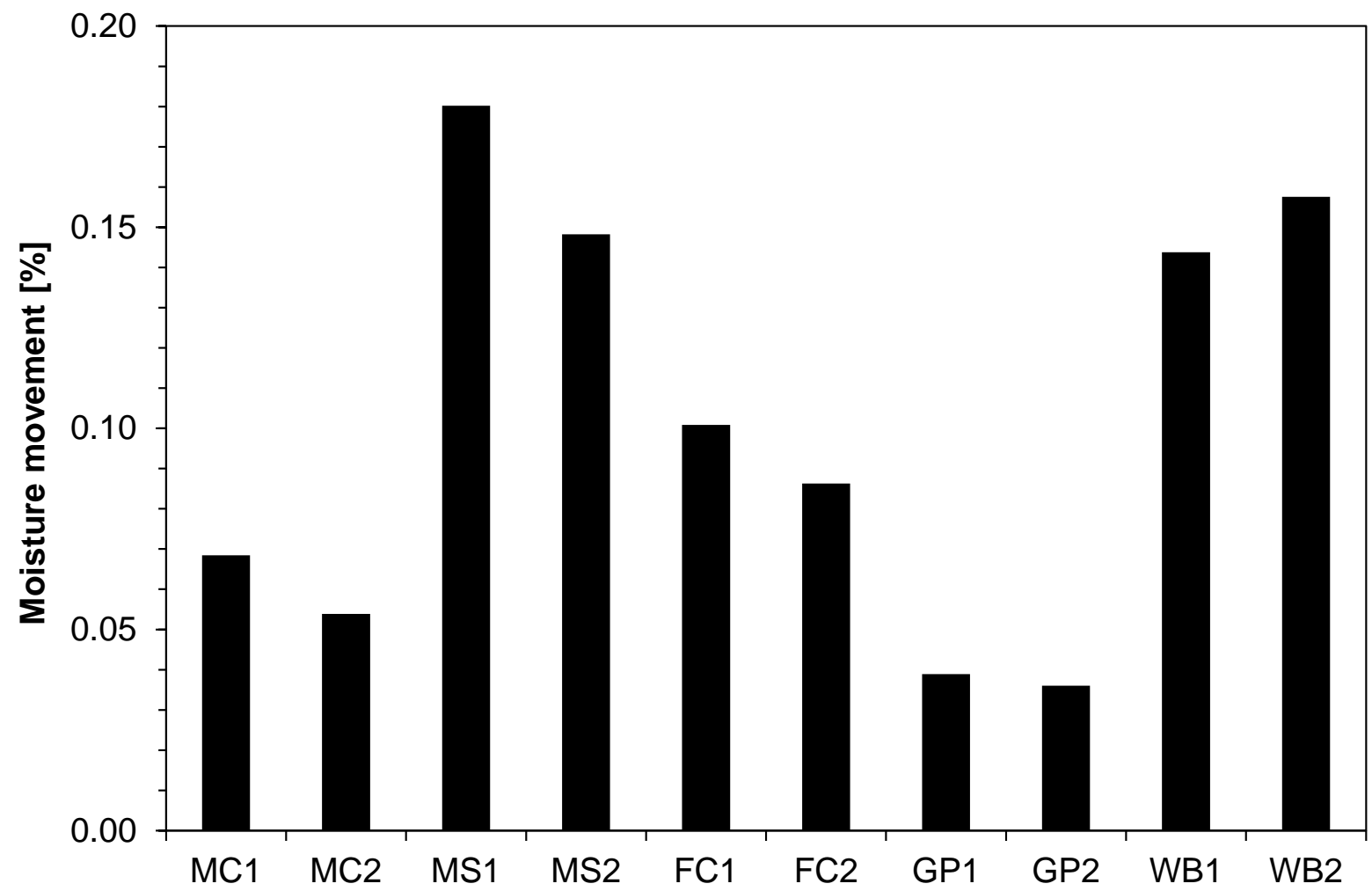

Fig. 10. Moisture movement (\%) for each board after 22 weeks exposure to $90 \% \mathrm{RH}$.

This research highlights that magnesium-based construction boards have many properties which are comparable or better than traditional board types. In terms of bending strength, they all had increased strength compared with gypsum plasterboards. MC1 had bending strength within the highest class (5) listed in BS EN 12467 [27], while the other magnesium based boards were within classes 2 and 3. The fibre cement boards were within class 4 and the wood-based boards within class 5 . The water absorption results for the magnesium-based boards were within the range of the other board types. This suggests the water absorption properties of magnesium-based boards are acceptable for use in the construction industry, as the other board types are all widely accepted as suitable for use.

In terms of durability the magnesium-based boards displayed good resistance to soak-dry and freezethaw tests. Visually, limited change was observed compared with the gypsum plasterboard's which suffered damage to their paper surface and the wood-based boards which underwent significant swelling. Significantly, less than $8 \%$ change in strength was observed after both soak-dry and freezethaw cycles for the magnesium-based boards. The only exception being MS2 which lost $13 \%$ of its bending strength following freeze-thaw cycles. The moisture movement test demonstrated less favourable behaviour for the magnesium sulphate boards. They underwent movement or expansion in the region of 0.15 and $0.18 \%$, similar to the wood-based boards. On the other hand, the magnesium oxychloride boards only had moisture movement values of 0.07 and $0.05 \%$. This suggests the 
magnesium oxychloride boards are more resistant to high levels of humidity than magnesium sulphate boards.

As previously mentioned, reports from Denmark have highlighted problems associated with magnesium-based boards in-service [11-13]. A previous study [14] has found that there is significant variation from one magnesium oxychloride board to another. Furthermore, the better performing boards provide significantly enhanced resistance to the type of failure observed in Denmark. This study has compared magnesium-based boards with widely accepted board types, (i.e. fibre cement, gypsum plasterboard and wood-based boards) used in the construction industry. As discussed above performance for magnesium-based boards, particularly magnesium oxychloride boards was often superior than for its counterparts. Therefore, magnesium-based boards appear a suitable material for use in the construction industry.

\section{Conclusions}

This study compared the performance of relatively novel magnesium oxychloride and oxysulphate construction boards against traditional board types including fibre cement, gypsum plasterboard and wood-based boards. The comparisons were made using existing standard test procedures for FC type boards in the first instance due to the absence of suitable test procedures for MC and MS boards. The following has been concluded:

- The bending strength and water absorption properties of the magnesium oxychloride and oxysulphate boards are comparable with fibre cement, gypsum plasterboards and wood-based boards.

- Magnesium oxychloride and oxysulphate boards performed better than gypsum plasterboard and wood-based boards during exposure to soak-dry and freeze-thaw cycles. The gypsum plasterboards suffered damage to their paper surface and became significantly weakened. Specifically, no strength was recorded after soak-dry cycles and they lost 36 and 52\% after freeze-thaw cycles. The wood-based boards underwent significant swelling, delamination and loss of strength (between 9 and 52\%). The performance of the magnesium-based boards was similar to that of the fibre cement boards with strength losses $\leq 13 \%$ observed.

- Magnesium oxychloride boards displayed good performance (0.07 and $0.05 \%)$ in the moisture movement test suggesting good resistance to expansion. On the other hand, the magnesium oxysulphate boards underwent a significantly larger expansion $(0.18$ and $0.15 \%)$. This is likely related to the stability of reaction products when exposed to high RH. The magnesium oxychloride boards also performed better than the fibre cement boards $(0.10$ and $0.09 \%)$ which appeared more susceptible to expansion, likely due to presence of cellulose fibres and their associated dimensional instability in the presence of moisture. 
This study has highlighted that the performance of magnesium oxychloride and oxysulphate boards is often superior or comparable to that of fibre cement, gypsum plasterboards and wood-based boards. In particular the magnesium oxychloride boards displayed good performance when exposed to high RH.

\section{Acknowledgements}

The authors appreciate the financial support received from Knowledge Transfer Partnership project (KTP11169) with Resistant Building Products which is partly funded by Innovate UK (No 511330) and Invest NI. The help received with sample preparation from Jamie Laing and Geoff Davis, Queen's University Belfast is also gratefully acknowledged.

\section{References}

[1] A. Manalo, Structural behaviour of a prefabricated composite wall system made from rigid polyurethane foam and Magnesium Oxide board, Constr. Build. Mater. 41 (2013) 642-653. https://doi.org/10.1016/J.CONBUILDMAT.2012.12.058.

[2] N. Jays, A. Olofinjana, D.J. Young, Assessing variability in the hygrothermal performance of magnesium oxide ( $\mathrm{MgO}$ ) cladding products of the Australian market, Constr. Build. Mater. 203 (2019) 491-500. https://doi.org/10.1016/J.CONBUILDMAT.2019.01.111.

[3] D. Pereira, A. Gago, J. Proença, T. Morgado, Fire performance of sandwich wall assemblies, $\begin{array}{llllll}\text { Compos. } & \text { Part } & B & \text { Eng. } & 93 & \text { (2016) }\end{array}$ https://doi.org/10.1016/J.COMPOSITESB.2016.03.001.

[4] C. Mao, Q. Shen, L. Shen, L. Tang, Comparative study of greenhouse gas emissions between off-site prefabrication and conventional construction methods: Two case studies of residential projects, Energy Build. 66 (2013) 165-176. https://doi.org/10.1016/J.ENBUILD.2013.07.033.

[5] M. Arashpour, R. Wakefield, B. Abbasi, E.W.M. Lee, J. Minas, Off-site construction optimization: Sequencing multiple job classes with time constraints, Autom. Constr. 71 (2016) 262-270. https://doi.org/10.1016/J.AUTCON.2016.08.001.

[6] M.R. Hosseini, I. Martek, E.K. Zavadskas, A.A. Aibinu, M. Arashpour, N. Chileshe, Critical evaluation of off-site construction research: A Scientometric analysis, Autom. Constr. 87 (2018) 235-247. https://doi.org/10.1016/J.AUTCON.2017.12.002.

[7] J.F. Montle, K.G. Mayhan, Magnesium oxychloride as a fire retardant material, J Fire Flammability/Fire $\quad$ Retard Chem. 11 (1974) 243-254. https://www.scopus.com/inward/record.uri?eid=2-s2.00016129576\&partnerID=40\&md5=3e95d1410fae11e9c9a96b6b2524b3da.

[8] W. Chen, J. Ye, Y. Bai, X.-L. Zhao, Full-scale fire experiments on load-bearing cold-formed steel walls lined with different panels, J. Constr. Steel Res. 79 (2012) 242-254. https://doi.org/10.1016/J.JCSR.2012.07.031. 
[9] W. Chen, J. Ye, Y. Bai, X.-L. Zhao, Improved fire resistant performance of load bearing coldformed steel interior and exterior wall systems, Thin-Walled Struct. 73 (2013) 145-157. https://doi.org/10.1016/J.TWS.2013.07.017.

[10] T. Runčevski, C. Wu, H. Yu, B. Yang, R.E. Dinnebier, Structural characterization of a new magnesium oxysulfate hydrate cement phase and its surface reactions with atmospheric carbon dioxide, J. Am. Ceram. Soc. 96 (2013) 3609-3616. https://doi.org/10.1111/jace.12556.

[11] K.K. Hansen, T. Bunch-Nielsen, B. Grelk, C. Rode, Magnesium-Oxide Boards Cause Moisture Damage Inside Facades in New Danish Buildings, in: Int. RILEM Conf. Mater. Syst. Struct. Civ. Eng., Lyngby, Denmark, 2016: pp. 151-161.

[12] C. Rode, T. Bunch-Nielsen, K.K. Hansen, B. Grelk, Moisture damage with magnesium oxide boards in Danish facade structures, Energy Procedia. 132 (2017) 765-770. https://doi.org/10.1016/J.EGYPRO.2017.10.025.

[13] M. Gravit, O. Zybina, A. Vaititckii, A. Kopytova, Problems of Magnesium Oxide Wallboard Usage in Construction, in: V. Murgul, Z. Popovic (Eds.), Int. Sci. Conf. Energy Manag. Munic. Transp. Facil. Transp. EMMFT 2017, Springer International Publishing, Cham, 2018: pp. 10931101.

[14] T.A. Aiken, M. Russell, D. McPolin, L. Bagnall, Magnesium oxychloride boards: Understanding of a novel building material, Mater. Struct. 53 (2020).

[15] M.A. Shand, The Chemistry and technology of Magnesia, John Wiley and Sons, Hoboken, USA, 2006.

[16] C.M. Gomes, Alternative binder for fibercement building materials, Adv. Mater. Res. 753-755 (2013) 616-622.

[17] C.M. Gomes, A.D.S. de Oliveira, Chemical phases and microstructural analysis of pastes based on magnesia cement, Constr. Build. Mater. $188 \quad$ (2018) 615-620. https://doi.org/10.1016/J.CONBUILDMAT.2018.08.083.

[18] S.A. Walling, J.L. Provis, Magnesia-Based Cements: A Journey of 150 Years, and Cements for the Future?, Chem. Rev. 116 (2016) 4170-4204. https://doi.org/10.1021/acs.chemrev.5b00463.

[19] Y.W. Mai, M.I. Hakeem, B. Cotterell, Effects of water and bleaching on the mechanical properties of cellulose fibre cements, J. Mater. Sci. 18 (1983) 2156-2162. https://doi.org/10.1007/BF00555010.

[20] J. Pritchard, M.P. Ansell, R.J.H. Thompson, P.W. Bonfield, Effect of two relative humidity environments on the performance properties of MDF, OSB and chipboard. Part 2. Fatigue and creep performance, Wood Sci. Technol. $35 \quad$ (2001) 405-423. https://doi.org/10.1007/s002260100108.

[21] R.Y. Vun, F.C. Beall, Monitoring creep-rupture in oriented Strandboard using acoustic emission: Effects of moisture contenta, Holzforschung. 58 (2004) 387-399. https://doi.org/10.1515/HF.2004.059. 
[22] B.J. Mohr, H. Nanko, K.E. Kurtis, Durability of kraft pulp fiber-cement composites to wet/dry cycling, Cem. Concr. Compos. $27 \quad$ (2005) 435-448. https://doi.org/10.1016/J.CEMCONCOMP.2004.07.006.

[23] M. Ardanuy, J. Claramunt, R.D. Toledo Filho, Cellulosic fiber reinforced cement-based composites: A review of recent research, Constr. Build. Mater. 79 (2015) 115-128. https://doi.org/10.1016/J.CONBUILDMAT.2015.01.035.

[24] N. Lushnikova, L. Dvorkin, Sustainability of gypsum products as a construction material, Sustain. Constr. Mater. (2016) 643-681. https://doi.org/10.1016/B978-0-08-100370-1.00025-1.

[25] M.S. Hassan, Moisture sensitivity and dimensional stability of carbonated fibre-cement composites, Adv. Cem. Res. 30 (2018) 413-426. https://doi.org/10.1680/jadcr.17.00141.

[26] W. Li, C. Mei, J. Van den Bulcke, J. Van Acker, The effect of water sorption/desorption on fatigue deflection of OSB, Constr. Build. Mater. 223 (2019) 1196-1203. https://doi.org/10.1016/J.CONBUILDMAT.2019.07.283.

[27] British Standards Institution, BS EN 12467:2012+A2:2018 Fibre-cement flat sheets - Product specification and test methods, London, UK, 2012.

[28] British Standards Institution, BS EN 323:1993 Wood-based panels - Determination of density, London, UK, 1993.

[29] British Standards Institution, BS EN ISO 15148:2002+A1:2016 Hygrothermal performance of building materials and products - Determination of water absorption coefficient by partial immersion, London, UK, 2002.

[30] K.L. Litherland, D.R. Oakley, B.A. Proctor, The use of accelerated ageing procedures to predict the long term strength of GRC composites, Cem. Concr. Res. 11 (1981) 455-466. https://doi.org/10.1016/0008-8846(81)90117-4.

[31] P. Purnell, N.. Short, C.. Page, A.. Majumdar, P.. Walton, Accelerated ageing characteristics of glass-fibre reinforced cement made with new cementitious matrices, Compos. Part A Appl. Sci. Manuf. 30 (1999) 1073-1080. https://doi.org/10.1016/S1359-835X(99)00019-6.

[32] A. Enfedaque, L.S. Paradela, V. Sánchez-Gálvez, An alternative methodology to predict aging effects on the mechanical properties of glass fiber reinforced cements (GRC), Constr. Build. Mater. 27 (2012) 425-431. https://doi.org/https://doi.org/10.1016/j.conbuildmat.2011.07.025.

[33] K. Schabowicz, T. Gorzelańczyk, M. Szymków, Identification of the degree of fibre-cement boards degradation under the influence of high temperature, Autom. Constr. 101 (2019) 190198. https://doi.org/10.1016/J.AUTCON.2019.01.021.

[34] R.S.P. Coutts, A review of Australian research into natural fibre cement composites, Cem. Concr. Compos. 27 (2005) 518-526. https://doi.org/10.1016/J.CEMCONCOMP.2004.09.003.

[35] S.K.S. Hossain, P.K. Roy, Development of sustainable calcium silicate board: Utilization of different solid wastes, Boletín La Soc. Española Cerámica y Vidr. 58 (2019) 274-284. https://doi.org/10.1016/J.BSECV.2019.06.003. 
[36] L. Kristanto, H. Sugiharto, S.W.D. Agus, S.A. Pratama, Calcium Silicate Board as Wall-facade, Procedia Eng. 171 (2017) 679-688. https://doi.org/10.1016/J.PROENG.2017.01.409.

[37] M. Chen, L. Lu, S. Wang, P. Zhao, W. Zhang, S. Zhang, Investigation on the formation of tobermorite in calcium silicate board and its influence factors under autoclaved curing, Constr. Build. Mater. 143 (2017) 280-288. https://doi.org/10.1016/J.CONBUILDMAT.2017.03.143.

[38] Z. Li, C.K. Chau, Influence of molar ratios on properties of magnesium oxychloride cement, Cem. Concr. Res. 37 (2007) 866-870. https://doi.org/10.1016/J.CEMCONRES.2007.03.015.

[39] C.K. Chau, Z. Li, Microstructures of magnesium oxychloride, Mater. Struct. 41 (2008) 853862. https://doi.org/10.1617/s11527-007-9289-y.

[40] V.M. Sglavo, F. De Genua, A. Conci, R. Ceccato, R. Cavallini, Influence of curing temperature on the evolution of magnesium oxychloride cement, J. Mater. Sci. 46 (2011) 6726. https://doi.org/10.1007/s10853-011-5628-z.

[41] B. Xu, H. Ma, C. Hu, S. Yang, Z. Li, Influence of curing regimes on mechanical properties of magnesium oxychloride cement-based composites, Constr. Build. Mater. 102 (2016) 613-619. https://doi.org/10.1016/J.CONBUILDMAT.2015.10.205.

[42] C. Hu, B. Xu, H. Ma, B. Chen, Z. Li, Micromechanical investigation of magnesium oxychloride cement paste, Constr. Build. Mater. $105 \quad$ (2016) 496-502. https://doi.org/10.1016/J.CONBUILDMAT.2015.12.182.

[43] X. Guo, F. Meng, H. Shi, Microstructure and characterization of hydrothermal synthesis of Alsubstituted tobermorite, Constr. Build. Mater. 133 (2017) 253-260. https://doi.org/10.1016/J.CONBUILDMAT.2016.12.059.

[44] V. Tserki, N.E. Zafeiropoulos, F. Simon, C. Panayiotou, A study of the effect of acetylation and propionylation surface treatments on natural fibres, Compos. Part A Appl. Sci. Manuf. 36 (2005) 1110-1118. https://doi.org/10.1016/J.COMPOSITESA.2005.01.004.

[45] P. Purnell, Degradation of fibre-reinforced cement composites, Durab. Concr. Cem. Compos. (2007) 316-363. https://doi.org/10.1533/9781845693398.316.

[46] P. Soroushian, J.-P. Won, M. Hassan, Durability characteristics of CO2-cured cellulose fiber reinforced cement composites, Constr. Build. Mater. 34 (2012) 44-53. https://doi.org/10.1016/J.CONBUILDMAT.2012.02.016. 